\title{
Aplikasi web promosi kuliner dan rumah makan online
}

\author{
Khairus Suhada ${ }^{1}$, Danuri ${ }^{2}$, Fajri Profesio Putra ${ }^{3}$ \\ ${ }_{1,2,3}$ Politeknik Negeri Bengkalis \\ ${ }^{1,2,3}$ Program Studi Rekayasa Perangkat Lunak, Jurusan Teknik Informatika \\ Jl. Bhatin Alam,Sungai Alam, Bengkalis, Riau, telp. +62 (766) 24566) \\ e-mail: ${ }^{1}$ assyuhada.140195@gmail.com, ${ }^{2}$ danuri@ polbeng.ac.id, ${ }^{3}$ fajri@polbeng.ac.id
}

\begin{abstract}
Abstrak
Kemajuan teknologi mendorong pertumbuhan dan perkembangan sektor perdagangan, usaha dan pemasaran. Tingginya tingkat keberhasilan dalam perdagangan didorong oleh berbagai faktor pendukung termasuk promosi dan periklanan. Melalui promosi dan periklanan yang tepat, perdagangan dibidang kuliner dapat tumbuh dengan baik. Memanfaatkan teknologi melalui aplikasi promosi kuliner dan rumah makan secara online dapat menjadi media promosi yang tepat. Aplikasi Web Promosi Kuliner dan Rumah Makan Online dibangun menggunakan metode System Development Life Cycle(SDLC). Perancangan sistem menggunakan Konteks diagram dan Data Flow Diagram (DFD) dan diterapkan menggunakan bahasa pemrograman PHP serta database MySQL. Aplikasi memberikan fasilitas berupa pencarian informasi seperti harga menu, alamat rumah makan, lokasi rumah makan serta kontak rumah makan. Fasilitas unggulan berupa fitur peta lokasi rumah makan yang terhubung dengan google map.
\end{abstract}

Kata kunci: aplikasi web, promosi kuliner dan rumah makan, google map

\begin{abstract}
Technological advances promote the growth and development of the trade, business and marketing sector. The high level of success in trading is driven by various supporting factors including promotion and advertising. Through proper promotion and advertising, culinary trade can grow well. Utilizing technology through culinary promotion apps and restaurants online can be the right promotional media. Web Application Culinary Promotion and Online Restaurant is built using System Development Life Cycle (SDLC) method. System design using Context diagrams and Data Flow Diagrams (DFD) and applied using PHP programming language as well as MySQL database. Application provides facilities in the form of information search such as menu price, restaurant address, restaurant location and restaurant contact. Excellent facility in the form of map location map of restaurant that connected with google map.
\end{abstract}

Keywords: web application, Culinary and restaurant promotion, google map .

\section{Pendahuluan}

Perkembangan teknologi informasi yang disertai perkembangan internet dimanfaatkan dan diterapkan dalam bisnis dan prusahaan (Indrajani dan Wily, 2007). Kemajuan informasi juga mengambil peranan dalam kemajuan teknologi, kemajuan ini menawarkan berbagai kemudahan dalam mencari dan menyebarluaskan sebuah informasi. Salah satu sarana yang dapat digunakan adalah dengan memanfaatkan teknologi jaringan internet. Jaringan internet saat ini tumbuh pesat dikarenakan penggunaan internet yang semakin luas salah satunya mengakses website. Menurut Badan Pusat Statistik (BPS) Kabupaten Bengkalis, pada tahun 2014 rata-rata dalam tiga bulan, penggunaan internet penduduk Kabupaten Bengkalis sebanyak 19,6 persen, 
angka ini lebih tinggi dibandingkan dengan tahun sebelumnya yang sebesar 14,61 persen (BPS Kabupaten Bengkalis, 2015).

Kemajuan informasi mampu mendorong kemajuan pada sektor-sektor tertentu misalnya perdagangan. Dengan kemajuan teknologi informasi misalnya internet, pemasaran dan promosi produk dapat dilakukan secara luas. Pemasaran dan promosi melalui intenet mampu mencakup wilayah yang luas. Sektor perdagangan Kabupaten Bengkalis tercatat mengalami peningkatan. Pada tahun 2014 perusahan perdagangan besar meningkat menjadi 138 setelah pada tahun sebelumnya tercatat sebanyak 77 prusahaan. Selain itu jumlah perdagangan menengah dan eceran juga mengalami peningkatan yang cukup besar pada tahun 2015 jika dibandingkan dengan kondisi tahun 2014 (BPS Kabupaten Bengkalis, 2015).

Melalui internet, kemajuan sektor perdagangan Kabupaten Bengkalis diharapkan dapat lebih ditingkatkan lagi. Khususnya perdagangan kuliner di Kabupaten Bengkalis dapat ditingkatkan melalui pemasaran dan periklanan produk dan rumah makan melalui internet. Pemasaran dan promosi dapat dilakukan dengan membangun sebuah website yang mampu menyediakan wadah bagi rumah makan yang ada di Kabupaten Bengkalis untuk mempromosikan produk nya.

Penerimaan pesanan, pelayanan dan penjelasan ketersediaan menu dan harga melalui tatap muka langsung dan telepon dirasa kurang efektif, sedangkan layanan telepon membebani rumah makan untuk menempatkan pegawai pada bagian layanan telepon dan memakan waktu yang banyak (Dewi dan Arnie, 2014). Sebuah rumah makan perlu memanfaatkan jaringan internet untuk digunakan sebagai promosi agar menarik minat pembeli (Husni, 2007). Memanfaat kan internet sebagai media pemasaran, dapat memudahkan pemilik usaha untuk memberikan pelayanan dan informasi terhadap konsumen secara optimal dan dapat diakses dimana saja dan kapan saja (Himawan dkk, 2014). Melihat permasalahan diatas, ini merupakan sebuah peluang yang dapat dimanfaatkan sebagai bisnis dalam penyediaan wadah beriklan secara luas. Membangun Aplikasi Promosi Kuliner dan Rumah Makan Secara Online Berbasis Web diharap mampu menjawab permasalahan diatas.

Sebuah penelitian terhadap rumah makan sipin jambi menggunakan rancang bangun aplikasi pemesanan secara online berbasis web menggunakan php dan Mysql. Aplikasi ini dapat diakses dengan internet dan dapat dijadikan sebagai media promosi bagi rumah makan (Kahar dkk, 2013). Dalam penelitian tersebut, aplikasi hanya terbatas pada satu buah rumah makan, pelanggan hanya dapat mengakses rumah makan sipin jambi. Perancangan dan pembuatan aplikasi Promosi Kuliner dan Rumah Makan akan terintegrasi secara online. Rumah makan di sekitar kota Bengkalis dapat mendaftarkan rumah makannya dan mempromosikan kuliner yang ditawarkan pada Aplikasi Promosi Kuliner dan Rumah Makan secara Online dan dapat diakses melalui webbrowser menggunakan gadget, smartphone maupun computer. Melalui Aplikasi, sebuah rumah makan dapat mempromosikan usahanya secara luas, meningkatkan penjualan dan meningkatkan jumlah pengunjung serta dapat mengembangkan usahanya.

Perancangan Aplikasi menggunakan pemrograman PHP dan MySql sebagai penyimpanan data dapat berjalan lebih baik (Batubara, 2012). Aplikasi Promosi Kuliner dan Rumah Makan dirancang berbasis web dengan menggunakan pemrograman php dan database MySQL. Melalui tools ini aplikasi lebih setabil dan dapat diakses melalui internet dengan webbrowser menggunakan berbagai platform baik itu gadget, smartphone maupun komputer. Beberapa peluang muncul melalui aplikasi berbasis internet, pembisnis dan prusahaan dapat bekerja sama karena kemudahan yang ditawarkan internet (Patil dkk, 2015).

\section{Metode Penelitian}

Guna mendukung penelitian, diperlukan data dan rancangan penelitian untuk menunjang penelitian dan dijelaskan sebagai berikut : . 


\subsection{Data Penelitian}

Untuk mendapatkan data yang dibutuhkan, diperlukannya pengumpulan data menggunakan sampel yang diambil dengan menerapkan metode observasi, wawancara dan studi pustaka. Data yang diambil merupakan data sampel rumah makan yang ada di Kecamatan Bengkalis dan sekitarnya. Pengambilan data berupa data produk hasilan dari rumah makan, nama, alamat dan data-data lainnya terkait informasi dari rumah makan. Adapun data yang dibutuhkan adalah :

1. Data pemilik rumah makan misalnya, nama, alamat dan jenis kelamin.

2. Data rumah makan misalnya alamat atau lokasi rumah makan.

3. Data produk atau menu yang disajikan oleh rumah makan.

4. Data harga menu yang ditawarkan

\subsection{Perancangan Sistem}

Perancangan aplikasi dibuat dengan Kontek Diagram dan DFD (Data Flow Diagram).

1. Kontek Diagram

Kontek Diagram Aplikasi Promosi Kuliner dan rumah Makan Secara Online Berbasis Web dapat dilihat pada gambar 1

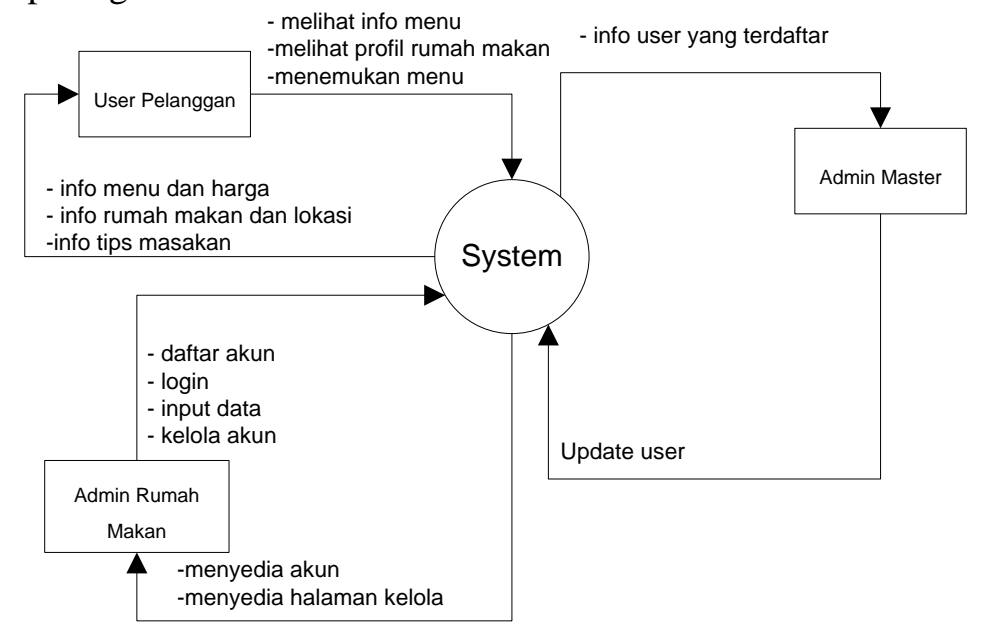

Gambar 1. Rancangan Kontek Diagram Aplikasi .

Kontek Diagram Aplikasi Promosi Kuliner dan Rumah Makan Secara Online Berbasis Web dapat dijelaskan sebagai berikut:

1. Pemilik rumah makan pada awalnya mendaftarkan rumah makan diaplikasi dengan menginputkan data-data yang dibutuhkan, selanjutnya pemilik rumah makan mendapatkan akun untuk dikelola.

2. Sistem menyediakan akun dan halaman kelola untuk dapat dikelola oleh pemilik rumah makan.

3. Pemilik rumah makan dalam hal ini adalah admin rumah makan dapat mengelola akun yang telah terdaftar, admin dapat mengimputkan data produk/menu, dan data rumah makan.

4. User dapat melihat info rumah makan yang disediakan oleh aplikasi. Info yang didapat berupa profil rumah makan, lokasi/alamat, menu dan harga.

5. User atau pelanggan dapat mencari rumah makan menu yang di saji sesuai keinginan dan selera. 
6. Admin master mampu mengelola seluruh sistem aplikasi dan sisitem dapat memberikan laporan jumlah user yang terdaftar kepada admin master.

2. Data Flow Diagram level 0 (DFD level 0)

Data Flow Diagram level 0 (DFD level 0) Aplikasi Promosi Kuliner Secara Online Berbasis Web dapat dilihat pada Gambar 3.

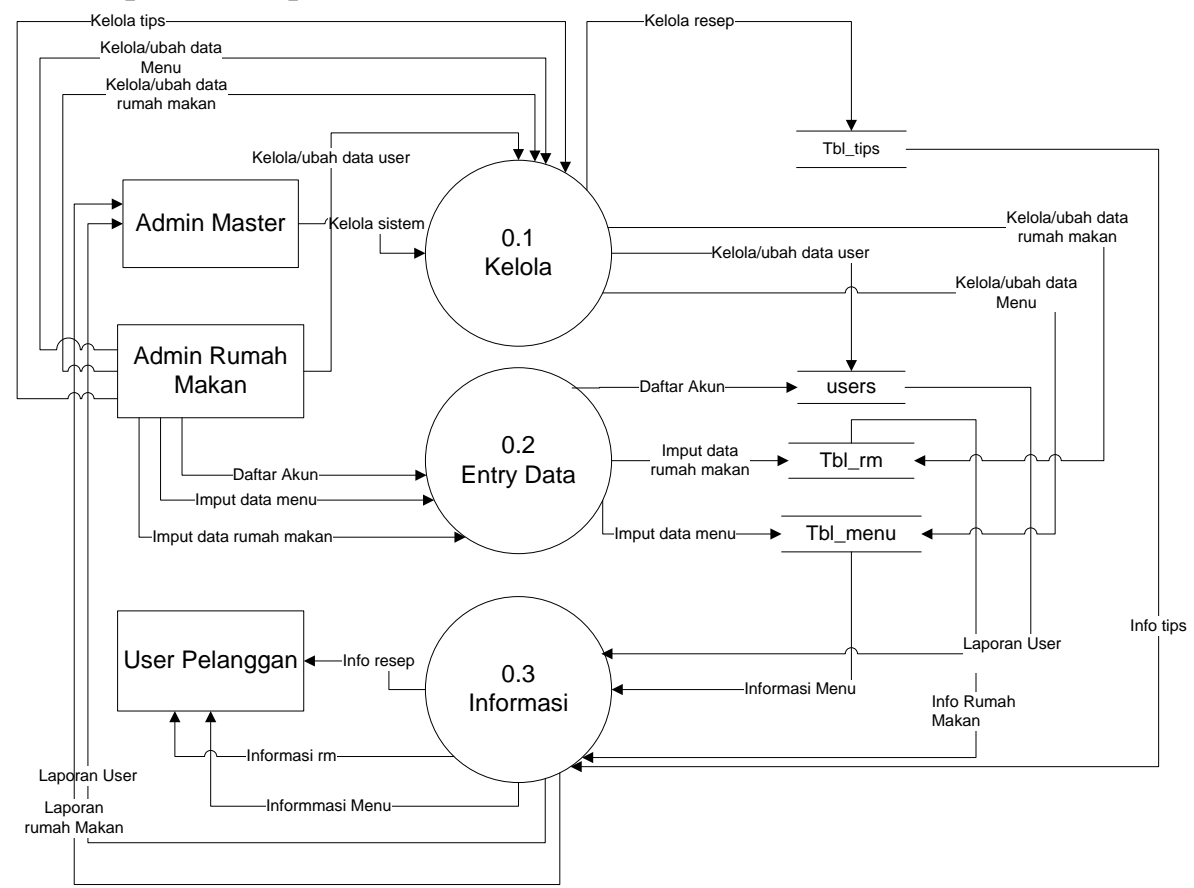

Gambar 2. Rancangan DFD level 0.

\section{Entity Relationship Diagram (ERD)}

Relasi antar tabel digunakan untuk menunjukkan hubungan secara logika diantara tabeltabel yang terbentuk (Nugroho dan Djajalaksana, 2014). Untuk lebih jelas rancangan relasi antar tabel menggunakan Logical Entity Relationship Diagram (ERD) dapat dilihat pada Gambar 4. 


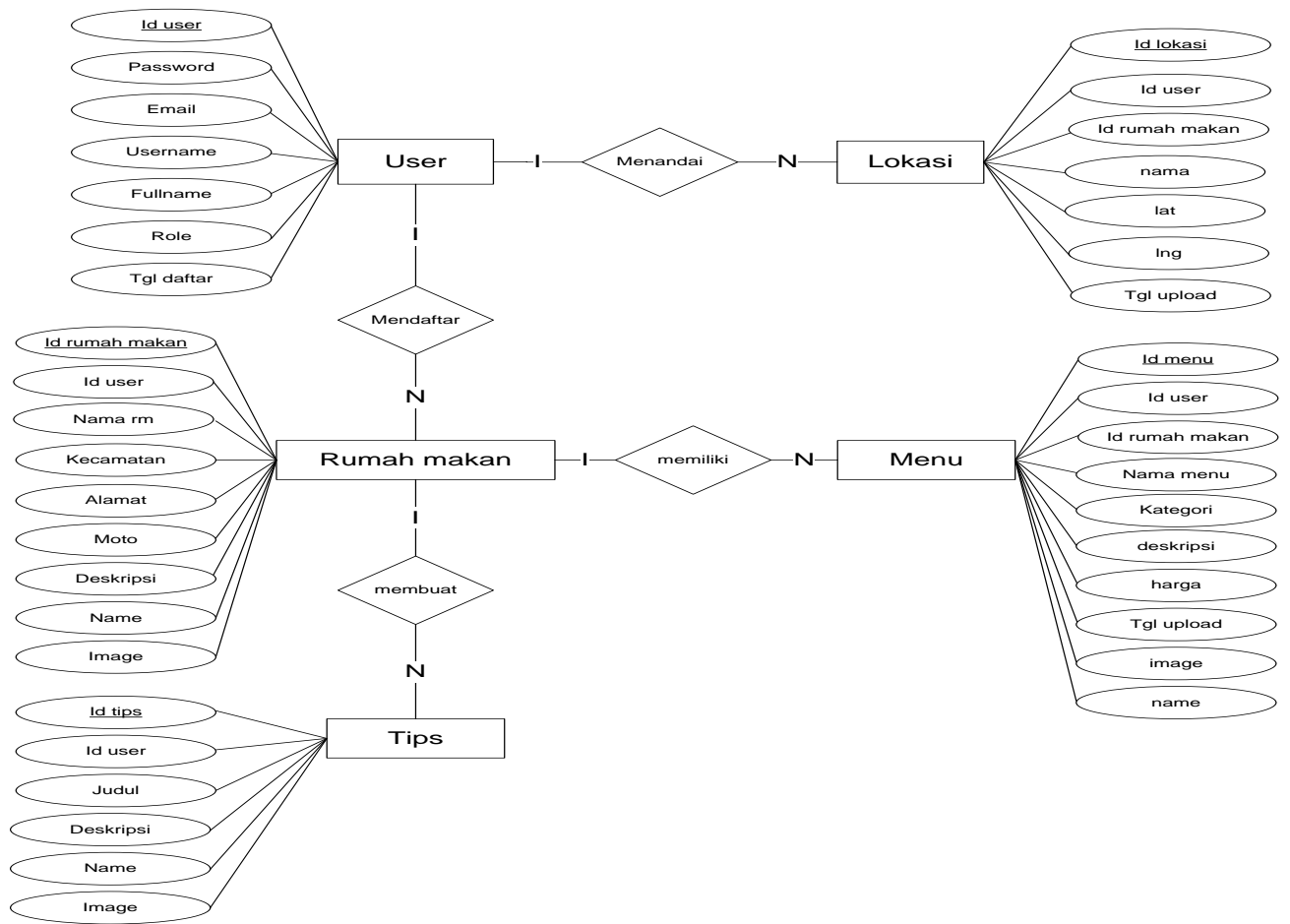

Gambar 3. Entity Relationship Diagram

\subsection{Perancangan Antarmuka}

Pada tahap ini dilakukan perancangan antar muka Aplikasi Promosi Kuliner dan Rumah Makan Secara Online Berbasis Web, perancangan ini terdiri dari perancangan masukan dan keluaran. Perancangan tampilan halaman antarmuka pengguna aplikasi atau pelnggan berfungsi untuk menata letak sehingga tampilan lebih menarik (Fadlah, 2012). Berikut adalah perancangan interface Aplikasi Promosi Kuliner dan Rumah Makan Secara Online Berbasis Web.

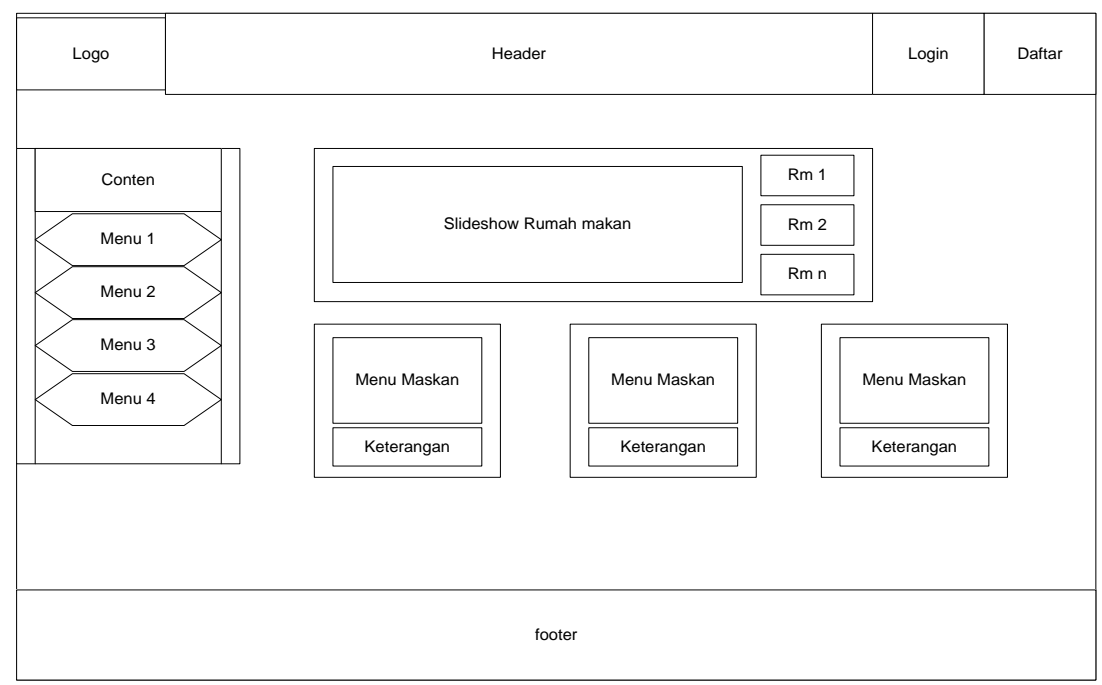

Gambar 4 Rancangan tampilan umum 


\section{Hasil dan Pembahasan}

\subsection{Hasil Penelitian}

Penelitian ini menghasilkan Aplikasi Promosi Kuliner dan Rumah Makan Secara Online Berbasis Web. User akun di aplikasi, setelah user terdaftar di aplikasi, user dapat membangun dan mengelola rumah makan diaplikasi. Melalui aplikasi ini pemilik rumah makan dapat mepromosikan rumah makan dan kuliner yang disediakan. Selain itu, Aplikasi juga menyediakan wadah untuk berbagi tips bagi user yang bersedia untuk berbagi tips masakannya. User, dalam hal ini adalah pengunjung aplikasi yang tidak terdaftar di aplikasi dapat membuka dan melihat rumah makan, kuliner dan tips yang terdapat di aplikasi. Pengunjung dapat mencari kuliner yang diinginkan serta rumah makan mana yang menyediakan kuliner tersebut. User juga dapat melihat alamat dan peta lokasi sebuah rumah makan melalui google map yang terhubung ke aplikasi.

\subsection{Pembahasan}

Pada tahap ini dilakukan pengujian sistem yang telah dirancang sebelumnya guna menguji fungsi dari setiap halaman aplikasi. Pengujian sistem meliputi pengujian input dan output Aplikasi. Pada pengujian ini dilakukan terhadap aplikasi melalui website dan webbrowser, pengujian ini bertujuan apakah fungsi Input dan Output aplikasi dapat berjalan dengan baik. Selanjutnya aplikasi juga diuji pada aplikasi webbrouser, apakah aplikasi telah mendukung webbrowser lain nya. Tampilan awal aplikasi dapat dilihat pada Gambar 5.

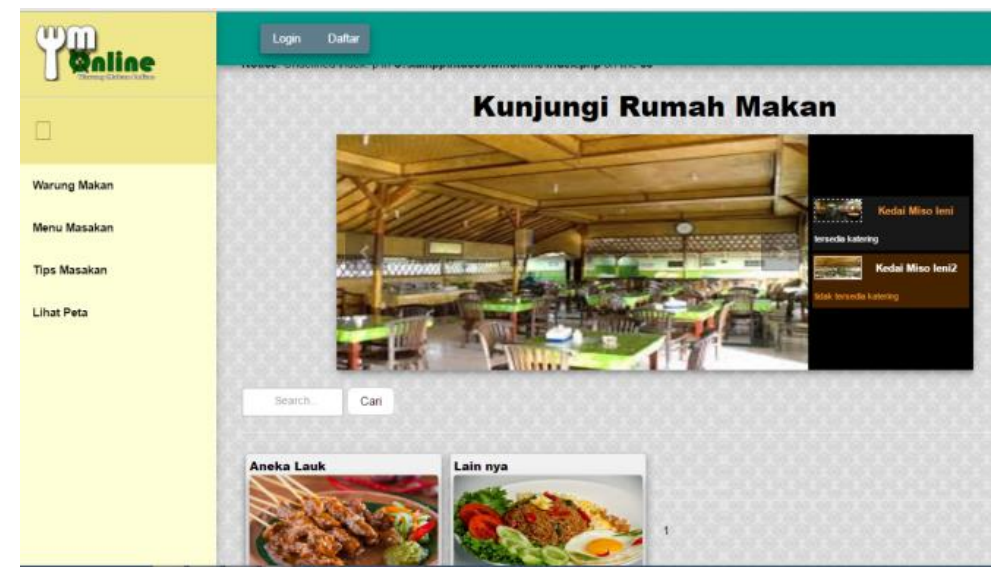

Gambar 5 Tampilan Home

Pengunjung aplikasi dapat melihat peta Rumah Makan yang terdaftar di aplikasi.

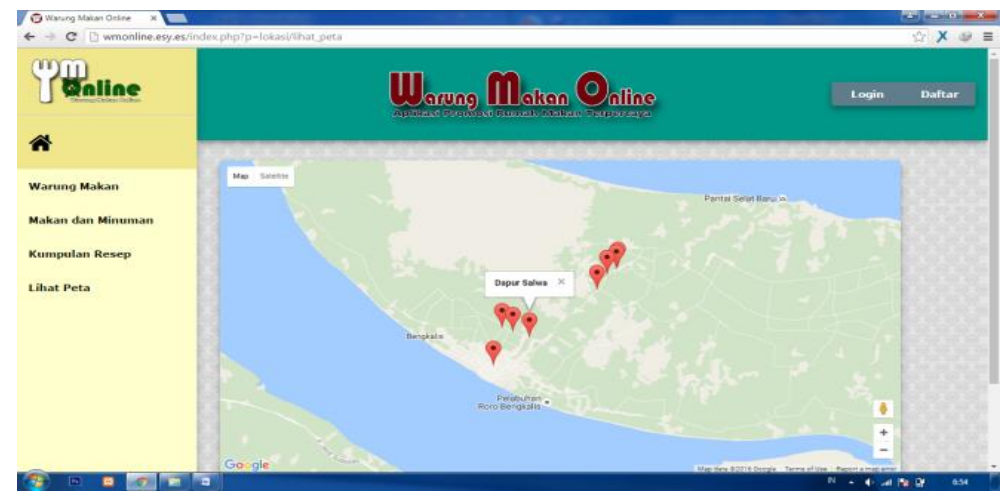

Gambar 6 Peta Rumah Makan yang terdaftar di Aplikasi 
User yang terdaftar dapat login kedalam aplikasi. User dapat mengelola akun yang telah terdaftar. Gambar tampilan utama pada sisi user dapat dilihat pada Gambar 9.

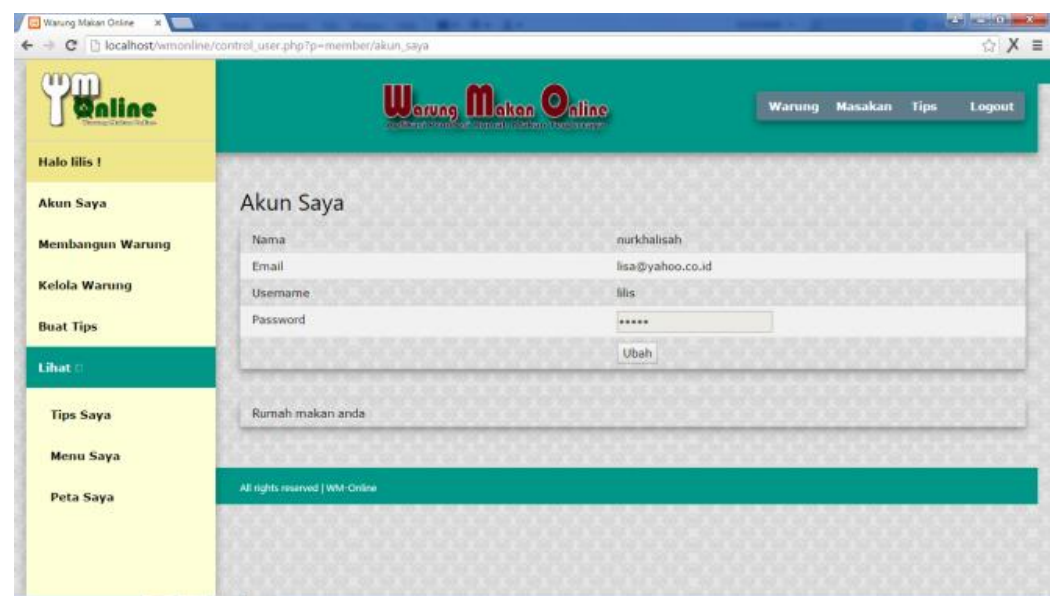

Gambar 7 Halaman control user pada sisi member

User dapat mengakses aplikasi melalui web brouser di smart phone. Gambar tampilan aplikasi pada versi browser android dapat dilihat pada Gambar 10.

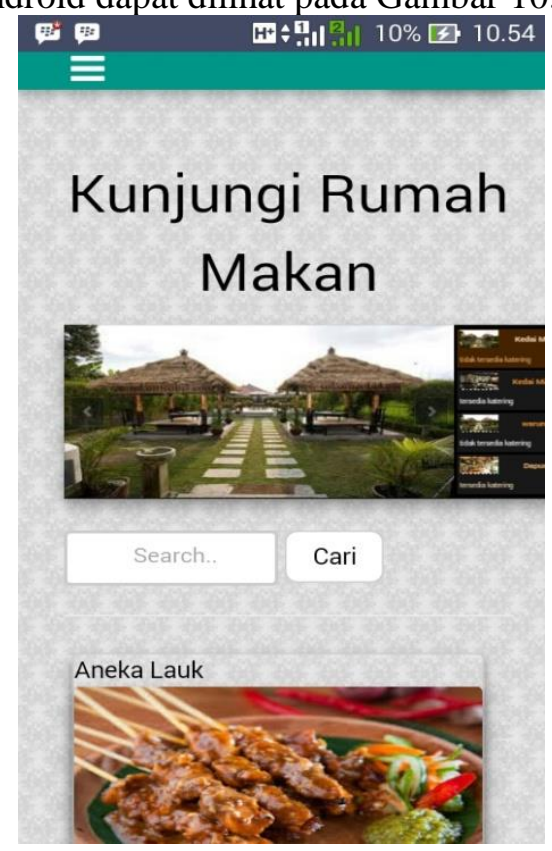

Gambar 8 Halaman utama pada web browser android

\section{Pengujian Black Box Data Input dan Output Aplikasi}

Tabel 1 Pengujian Input dan Output

\begin{tabular}{|c|l|l|l|}
\hline \multirow{2}{*}{ NO } & \multicolumn{1}{|c|}{ Pengujian } & \multicolumn{2}{|c|}{ Hasil } \\
\cline { 3 - 4 } & & Berhasil & Gagal \\
\hline A & Proses Input & & \\
\hline 1 & Daftar akun & $\checkmark$ & - \\
\hline
\end{tabular}




\begin{tabular}{|c|l|l|l|}
\hline 2 & Daftar Rumah makan & $\checkmark$ & - \\
\hline 3 & Buat Menu & $\checkmark$ & - \\
\hline 4 & Tandai lokasi rumah makan & $\checkmark$ & - \\
\hline 5 & Input resep & $\checkmark$ & - \\
\hline B & Proses Lihat Data & & \\
\hline 1 & Lihat data user terdaftar & $\checkmark$ & - \\
\hline 2 & Lihat data rumah makan terdaftar & $\checkmark$ & - \\
\hline 3 & Lihat data menu & $\checkmark$ & - \\
\hline 4 & Lihat data tips & $\checkmark$ & - \\
\hline 5 & Lihat Lokasi rumah makan & $\checkmark$ & \\
\hline
\end{tabular}

Pada tahap pengujian Input dan Output, aplikasi dapat dijalankan dengan baik, tanpa menghadapi kendala yang berarti. Dengan kata lain input dan output aplikasi telah berhasil dan sukses dijalankan.

\section{Pengujian pada Webbrowser}

Pengujian aplikasi melalui Webbrowser bertujuan untuk mengetahui apakah aplikasi dapat berjalan dengan baik pada aplikasi browser. Aplikasi dapat dijalan kan pada webbrowser versi desktop dengan mengakses link http://wmonline.esy.es/

Tabel 2 Pengujian pada webbrowser

\begin{tabular}{|c|c|c|c|l|}
\hline No & Browser & Versi & Hasil & \multicolumn{1}{|c|}{ Keterangan } \\
\hline 1 & $\begin{array}{c}\text { Google } \\
\text { Chrome }\end{array}$ & $\begin{array}{c}51.0 .27 \\
04.84\end{array}$ & Berhasil & $\begin{array}{l}\text { Aplikasi dapat dijalankan } \\
\text { dengan baik. Semua tampilan } \\
\text { dan form input berhasil diuji. }\end{array}$ \\
\hline 2 & $\begin{array}{c}\text { Mozilla } \\
\text { Firefox }\end{array}$ & 30.0 & Berhasil & $\begin{array}{l}\text { Aplikasi dapat dijalankan } \\
\text { dengan baik. Semua tampilan } \\
\text { dan form input berhasil diuji. }\end{array}$ \\
\hline 3 & Opera & 28.0 & Berhasil & $\begin{array}{l}\text { Aplikasi dapat dijalankan } \\
\text { dengan baik. Semua tampilan } \\
\text { dan form input berhasil diuji. }\end{array}$ \\
\hline 4 & Browser & Asus \\
android asus & zen fone c & B V. & Berhasil & \\
& & $\begin{array}{c}\text { Kitkat } \\
\text { zense }\end{array}$ & & $\begin{array}{l}\text { Pada versi browser smart } \\
\text { phone, aplikasi dapat berjalan } \\
\text { dengan baik }\end{array}$ \\
\hline
\end{tabular}

Pengujian pada webbrowser versi dekstop dapat dijalan kan dengan baik, semua menu navigasi dan fitur yang terdapat di aplikasi dapat dijalan kan dan difungsikan sebagai mana mestinya. Aplikasi menemui kendala ketika diakses melalui webbrowser smart phone, ketika user mengakses halaman control user, ada beberapa menu navigasi yang tidak dapat di akses. Akan tetapi aplikasi tetap berjalan dengan baik ketika user mengakses halaman utama atau halaman index.

\section{Hasil Pengujian}

Hasil pengujian pada apalikasi dapat disimpulkan sebagai berikut:

1. Berdasarkan hasil yang diperoleh dari Tabel 1 pengujian data input dan output tercatat mengalami keberhasilan. Fitur yang terdapat pada aplikasi dapat dijalankan sebagai mana mestinya. 
2. Berdasarkan hasil yang diperoleh dari Tabel 2 Aplikasi Promosi Kuliner dan Rumah Makan Secara Online Berbasis Web dapat dijalankan dengan baik menggunakan webbrowser versi desktop seperti Google Chrome versi 51.0.2704.84, Mozilla Firefox versi 30.0, Opera Mini dan Internet Explor. Sedangkan pengujian menggunakan webbrowser versi mobile seperti browser android asus zen fone c V 2.0.3 Kitkat berhasil di jalankan. Pada halaman index aplikasi dapat dijalankan dengan baik, dan fitur aplikasi dapat digunakan sebagai mana mestinya.

\section{Kesimpulan}

Berdasarkan hasil penelitian dan pembahasan Aplikasi Promosi Kuliner Secara Online Berbasis Web sebelumnya, dapat disimpulkan bahwa:

1. Website yang telah dibuat dapat memberikan informasi tentang rumah makan dan kuliner yang ditawarkan rumah makan kepada pengunjung aplikasi.

2. Melalui Aplikasi WM-Online, rumah makan dapat mempromosikan rumah makan dan menu masakannya lebih luas dan gratis. Selanjutnya melalui aplikasi WM-Online ini, diharapkan mampu meningkatkan jumlah pengunjung dan omset penjualan pada rumah makan.

3. Aplikasi WM-Online dapat digunakan dan diakses dengan baik melalui aplikasi webbrowser.

\section{Daftar Pustaka}

[1] Anonim., 2015, Statistik Daerah Kabupaten Bengkalis 2015, Badan Pusat Statistik Kabupaten Bengkalis, Bengkalis

[2] Dewi, S.P., dan Arnie, R., 2014, Aplikasi Layanan Pemesanan Katering Pada Rumah Makan Srie Berbais Web, JUTISI, ( 3 ), 3, 645-652

[3] Batubara, F.A., 2012, Perancangan Website Pada PT. Ratu Enim Palembang, Jurnal Ilmu Pengetahuan dan Teknologi Terapan, ( 7 ), 3, 15-27

[4] Fadilah, A.A., 2012, Rancang Bangun Aplikasi Pemesanan Makanan Dengan PHP dan MySQL,

[5] Himawan., Sefullah, A., dan Santoso, S., 2014, Analisa dan Perancangan Sistem Informasi Penjualan Online (E-Commerce) pada CV Selaras Batik Menggunakan Analisa Deskriptif, Scientific journal of informati, ( 1 ), 1, 53-64

[6] Husni., 2007, Pemrograman Database Berbasis Web, Graha Ilmu, Yogyakarta

[7] Indrajani., dan Wily., 2007, Analisis dan Perancangan Sistem Penjualan Berbasis Web pada PT. Sarang Imitasi, Seminar Nasional Teknologi, 1-9

[8] Kahar, N., Astutui, R.W., dan Reni., 2013, Aplikasi Pemesanan Makanan Online Berbasis Web pada Rumah Makan Pagi Sore Sipin Jambi, Jurnal Informatika, ( 7 ), 2 , 792-801

[9] Nugroho, J.S., dan Djajalaksana, Y,M., 2014., Aplikasi Web Reservasi dan Penjualan untuk Restoran, Jurnal Sistem Informasi, ( 2 ), 2, 127-147

[10] Patil, P., Salunke, C., Patil, S., dan Verma., A., 2015, Online Meal system using web portal (E-meal), International Research Journal of engineering and Technology (IRJET), ( 2 ), 08, 1501-1504 